\title{
High-density surveys conducted to reveal active deformations of the upper forearc slope along the Ryukyu Trench, western Pacific, Japan
}

\author{
Kohsaku Arai ${ }^{*} \mathbb{D}$, Takahiko Inoue and Tomoyuki Sato
}

\begin{abstract}
In this study, which was conducted to investigate present-day geological deformations occurring off the central Ryukyu Arc along the Ryukyu Trench (Okinawa-jima) in the vicinity of Japan, we obtained and examined dense, high-resolution, 2D grid (high-density) multichannel seismic reflection data. The forearc slope of the central Ryukyu Arc lacks a large forearc basin but has a steep narrow slope that dips to the southeast in the direction opposite to the plate convergence. However, while the seismic profiles obtained in our investigation do not reveal any active structures indicative of compressional stress in this convergent subduction zone, recent tectonic deformations are characterized by normal faults that strike perpendicular to the Ryukyu Trench axis. Examinations of high-density geological data show that the recent relative motion of the overriding plate has resulted in an active, arc-parallel extensional field. Furthermore, the results of our observations indicate two stages of extensional stress beneath the forearc slope of the central Ryukyu Arc that resulted from back-arc rifting in the Okinawa Trough.
\end{abstract}

Keywords: Normal fault, Active deformation, Ryukyu Trench, Subduction, High-resolution seismic profile

\section{Introduction}

Some of the world's largest earthquakes, such as the $\mathrm{Mw}$ 9.3 Sumatra-Andaman Earthquake and the Mw 9.0 Great East Japan Earthquake off Tohoku, along with their associated tsunamis, were natural disasters of historic proportions. The seriousness of these events underscores the need for further detailed investigations of the active geological structures in and around the source areas of these earthquakes and tsunamis, particularly at the plate convergent margins. The Ryukyu subduction zone is one such region that requires further study (Ando et al. 2009) because of the numerous tsunami boulders that can be found widely scattered along the coasts of the southern Ryukyu Arc (e.g., Araoka et al. 2013).

The tectonic similarity of the southern Ryukyu Arc with the Sumatra-Andaman subduction zone is characterized by oblique convergence (Letouzey and Kimura 1986; Lin et al. 2014), which indicates similar risk levels

\footnotetext{
*Correspondence: ko-arai@aist.go.jp

The Research Institute of Geology and Geoinformation, Geological Survey of Japan, AIST, Tsukuba Central 7 AIST, 1-1-1 Higashi, Tsukuba, Ibaraki, Japan
}

in terms of large earthquakes and tsunamis. Earthquakes of magnitude greater than $8.0(\mathrm{Mw})$ have not been recorded in the past 350 years (Watanabe 1985) in the Ryukyu Arc. The largest earthquake that occurred was an Mw 7.4 event in the Sakishima Islands in the southern Ryukyu Arc (Watanabe 1985), which was followed by a tsunami (referred to as the Meiwa Tsunami of 1771). This $>30 \mathrm{~m}$ high tsunami deposited numerous large coral boulders when it hit the Sakishima Islands (e.g., Nakata and Kawana 1995; Watanabe 1985). Such coral boulders have been known to provide useful geological paleo-tsunami records for estimating the recurrence intervals of large earthquakes along the Ryukyu Trench (e.g., Araoka et al. 2013; Goto et al. 2010). For example, Goto et al. (2013) described the clast sizes of such coastal boulders, from which they identified the local occurrence of tsunamigenic earthquakes along the Ryukyu Arc. Although that study found no evidence of tsunamis in the central Ryukyu Arc (between Amami-o-shima and Okinawa-jima) during at least the past 2300 years, another large (Mw 7.1) earthquake, in which numerous houses 
were damaged (Tsuji 1997), was recorded off Kikai-jima in the northernmost area of the central Ryukyu Arc in 1995. Currently, active deformations on the upper forearc slope are being investigated using high-density seismic reflection surveys in the hope that they will assist in assessing the occurrence likelihood of future large earthquakes and tsunamis in this region.

In this study, we report on the results of a mapping project conducted by the Geological Survey of Japan (GSJ) of the National Institute of Advanced Industrial Science and Technology (AIST) in waters around Okinawa-jima, which is located in the center of the Ryukyu Arc, between 2008 and 2010. Part of the survey area to the southeast of Okinawa-jima is on the upper forearc slope of the central Ryukyu Arc. As part of this project, we obtained and examined systematic highdensity seismic reflection data for the upper forearc slope. Herein, we present the results of our investigation, which focuses on the stratigraphy of the offshore sedimentary units along the Ryukyu Trench, recent deformational features, and geological structures.

\section{Geological setting}

The Ryukyu Arc extends for over $1200 \mathrm{~km}$ along the eastern coast of Asia from Kyushu to Taiwan (Fig. 1). The major islands of the Ryukyu Arc are considered the forearc highs (Kizaki 1978; Letouzey and Kimura 1986) and, along with the associated Ryukyu Trench, are products of subduction of the Philippine Sea Plate (PSP) beneath the Eurasian Plate. The PSP is subducting northwestward beneath the Eurasian Plate at a convergence rate of 4-9 $\mathrm{cm} /$ year (Seno et al. 1993). The Okinawa Trough is a back-arc basin located beside the Ryukyu Arc that was formed in the late Miocene (Gungor et al. 2012) or the late Pliocene-early Pleistocene (Park et al. 1998; Shinjo 1999; Sibuet et al. 1998). Formation of the Okinawa Trough was a key geological event associated with complex tectonism and changes in the topographic configuration of the Ryukyu Arc. The Ryukyu Arc itself is divided into three regions (northern, central, and southern) by the Tokara Strait and the Kerama Gap (e.g., Konishi 1965). The pre-Neogene accretion and metamorphic belts that are recognized in southwestern Japan can be traced into the Ryukyu Arc. The geological zones of the metamorphic belts are displaced by a NW-SE-trending left-lateral fault along the Tokara Strait (Kizaki 1978; Konishi 1965), beneath which a depression with water depths reaching $1400 \mathrm{~m}$ (Fig. 1) has been formed. The central and southern Ryukyus are separated by the Kerama Gap (i.e., the Miyako Depression), where water depths reach $2100 \mathrm{~m}$ (Kato et al. 1982) in the depression between Okinawa-jima and Miyako-jima. Our study area is located in the central Ryukyu Arc.

\section{Methods/Experimental}

\section{Seismic data acquisition}

Several 16-channel high-resolution seismic reflection surveys were carried out around Okinawa-jima during cruises from 2008 to 2010 (GH08 cruise = July 28 to August 29, 2008; GH09 cruise = July 16 to August 17, 2009; GH10 cruise = October 27 to November 25, 2010) aboard the R/V Hakurei-maru No. 2 operated by the Japan Oil, Gas and Metals National Corporation (JOG$\mathrm{MEC}$ ). The area studied is the upper forearc slope off Okinawa-jima in the central Ryukyu Arc (Figs. 1 and 2). More than 12,000 km of high-resolution seismic profiles were acquired during these cruises, primarily with GI-gun systems using a 16-channel digital streamer cable. Ship speeds during the cruises were maintained at approximately 8 knots. The shot interval of the 355 GI guns (4096.7 $\mathrm{cm}^{3}$ generator and $1720.6 \mathrm{~cm}^{3}$ injector) was $6 \mathrm{~s}$. The data recording length was $5.9 \mathrm{~s}$ and the sampling rate was $2 \mathrm{~ms}$. The water depth of the GI gun and streamer cable was maintained at 3-5 $\mathrm{m}$ for these high-resolution surveys. A differential global positioning system was used for navigation and positioning during the surveys. Digital data were recorded with a CNT-2 (Geometrics, Inc., San Jose, CA) seismic system and then saved in SEG-D format, which is currently recommended by the Society of Exploration Geophysicists, prior to being processed onboard using Seismic Processing Workshop (SPW) software (Parallel Geoscience Corp., Incline Village, NV). Processing of the 16-channel seismic data was performed using common-midpoint (CMP) sorting, 30 to $120 \mathrm{~Hz}$ bandpass filtering, gain control, deconvolution, normal move out (NMO), and CMP stacking. Bathymetric surveys using a Hydrosweep DS-3 multi-narrow-beam swath sonar (ATLAS Hydrographic, GmbH, Bremen, Germany) were conducted along the seismic survey lines (Fig. 2).

\section{Results \\ Sedimentary units and stratigraphy}

The sedimentary units and geological structures in the study area were examined using the collected seismic profiles. Seismic reflections below the upper forearc slope show a distinct reflector that may represent the upper boundary of the acoustic basement off northern (Fig. 3) and central Okinawa-jima (Fig. 4). This reflector dips to the southeast and is overlain by stratified sediments. The acoustic basement crops out and is exposed on the Hedo Bank, which is located between Okinawa-jima and Yoron-jima (Fig. 5). The sediments on the upper forearc slope overlying the unconformity on the top of the acoustic basement can be divided into four seismic units. The lower unit (seismic unit A), which has the same dip as the top of the acoustic basement, shows continuous high-amplitude internal reflectors and is restricted to the area southeast off northern 


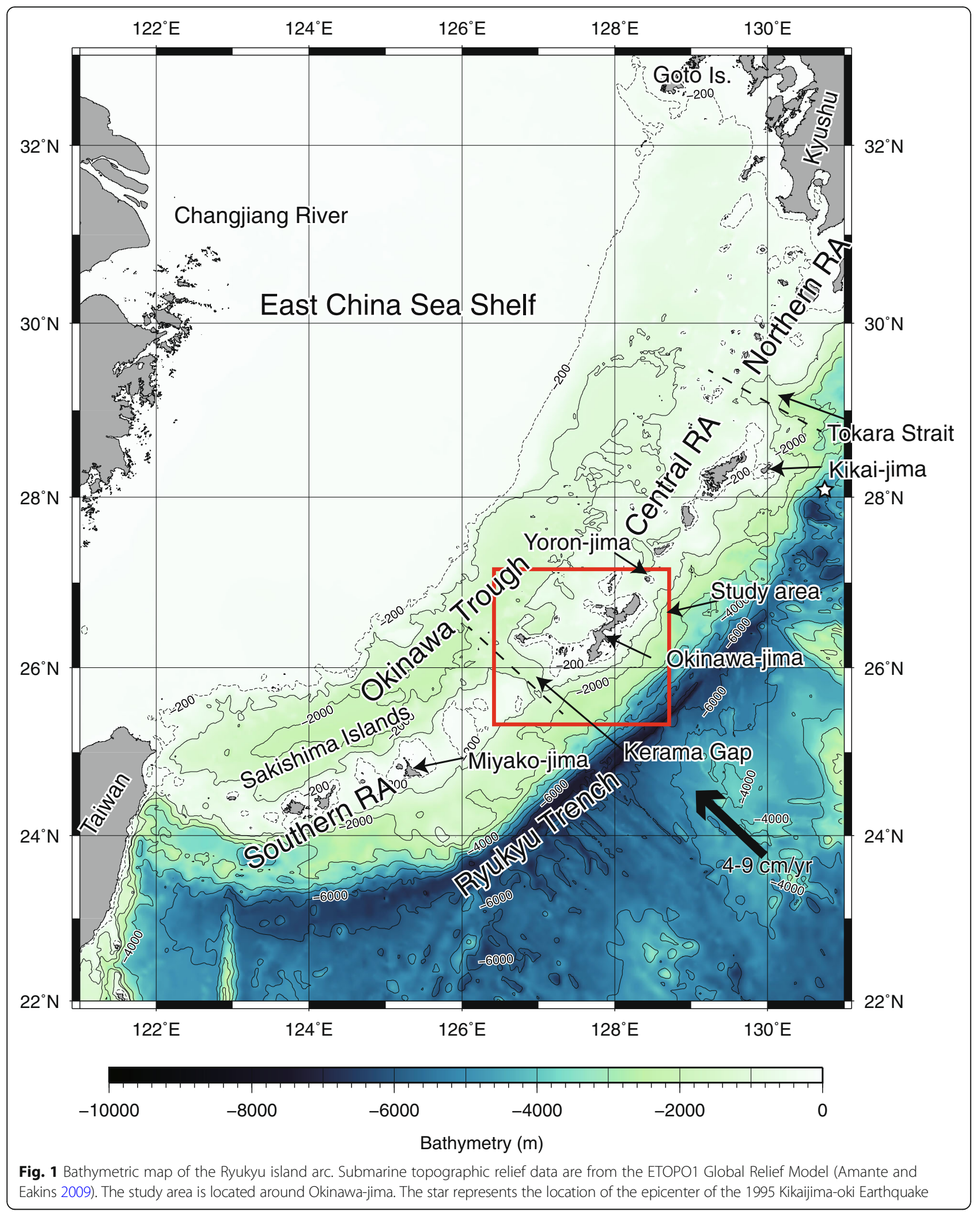




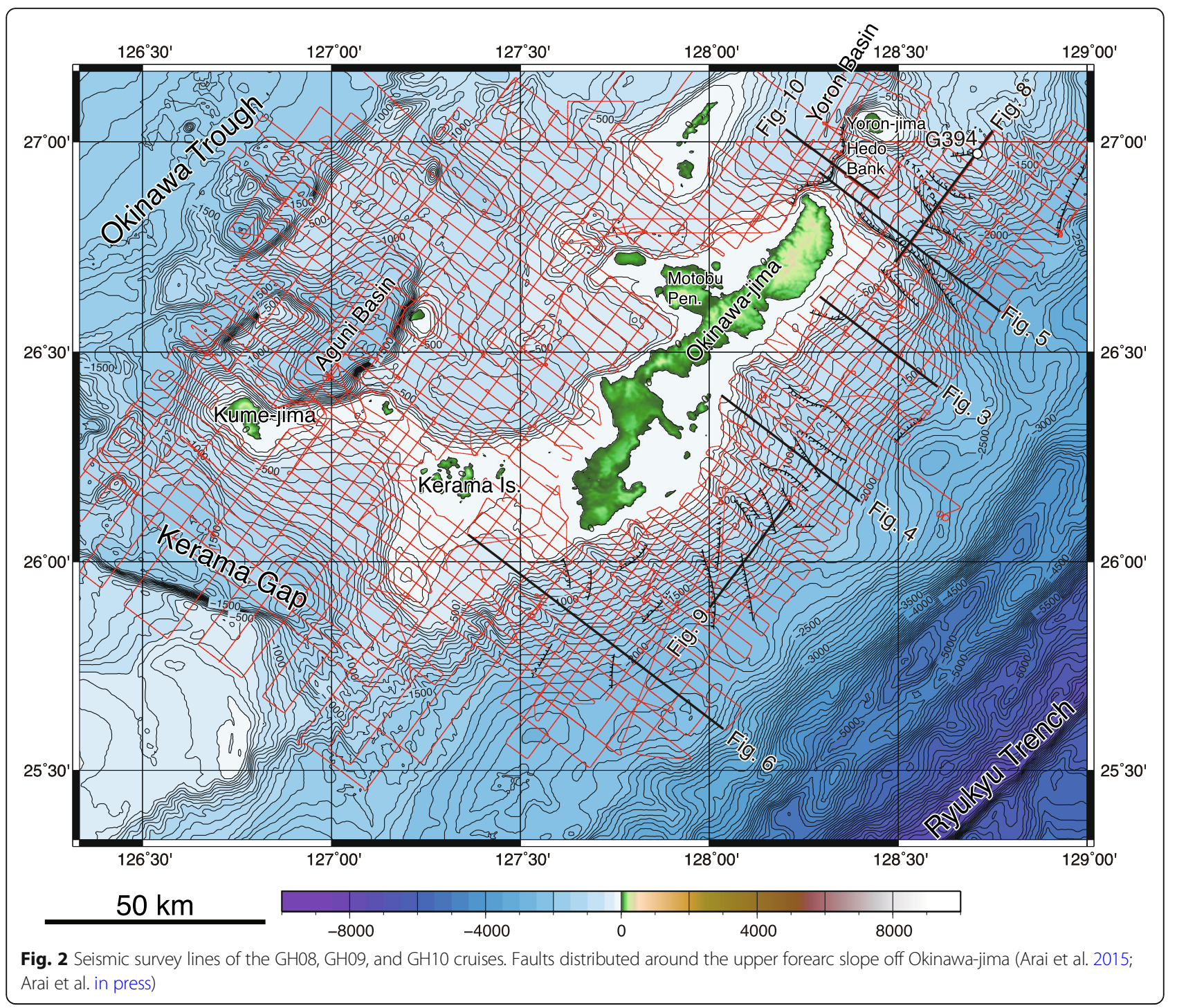

Okinawa-jima. The thickest portion of this unit has a $1.0 \mathrm{~s}$ two-way travel time (TWT), and the erosional truncation at its top is clearly evident beneath the island shelf. Seismic unit B is characterized by stratified sediment that dips gently to the southeast and has continuous internal reflectors. This unit typically onlaps onto the top of the acoustic basement and seismic unit A. Seismic unit B tends to be thicker in the southwestern part of the study area and has a maximum thickness of $2.0 \mathrm{~s}$ TWT (Fig. 6). Seismic unit C runs sub-parallel to seismic unit B and has high-amplitude stratified reflectors and good continuity. This unit typically onlaps onto seismic unit B (Figs. 3, 4, 5, and 6) and has a maximum thickness of $0.8 \mathrm{~s}$ TWT. The upper unit (seismic unit D), which comprises thin sediments (0.3 s TWT) sub-parallel to the seafloor, also has high-amplitude stratified reflectors and good continuity. This unit onlaps onto seismic unit $C$ (Figs. 4 and 6).
We obtained 28 consolidated or semi-consolidated samples from the sea bottom subsurface from which calcareous nannofossil biostratigraphic ages were revealed (e.g., Tanaka 2009). The acoustic basement is widely distributed and based on samples collected from Hedo Bank, which is believed to comprise pre-Neogene rocks. Nannofossil biostratigraphic analysis has shown that seismic unit $B$ is of late Pliocene age and that seismic unit $C$ is Pleistocene in age (Fig. 7; Arai et al. 2015). Given these ages, seismic unit B can be correlated to the Shimajiri Group (siltstone and sandstone) in southern Okinawa-jima, which ranges in age from late Miocene to early Pleistocene (Fukuta et al. 1969), while seismic units C and D correspond to the Ryukyu Group, which comprises the same Pleistocene carbonate deposits that are found throughout Okinawa-jima and other islands in the region (Iryu et al. 2006). 




\section{Characteristics of active structures}

Geological structures were examined using dense 2D grid data at 2-mile intervals along track directions perpendicular to the trench axis and at 4-mile intervals parallel to the trench axis. No obvious deformations, such as folds and faults, were found beneath the upper forearc slope parallel to the Ryukyu Trench axis (Figs. 3, 4, 5, and 6). In contrast, a number of active faults striking perpendicular to the Ryukyu Trench axis (NW-SE direction) were observed (Fig. 2). The most conspicuous normal faults were found to the north and south of Okinawa-jima. An example to the north of Okinawa-jima and Yoron-jima is shown in Fig. 8. This fault dips $60-80^{\circ}$ to the northeast and, based on seismic stratigraphy and calcareous nannofossil biochronology (Arai et al. 2010), appears to have been active since the late Miocene (the age of seismic unit B). The maximum vertical displacement of the basement is $700 \mathrm{~ms} \mathrm{TWT}$ and the basal termination of seismic unit D occurs at $250 \mathrm{~ms}$ TWT near the fault (Fig. 8). During the 2008 cruise, olive gray mudstone (G394) was obtained with a grab sampler east of Yoron-jima along the survey line shown in Fig. 8 at a water depth of $871 \mathrm{~m}$. This sample, which contained well-preserved calcareous nannofossils (Tanaka 2009), was formed during the period defined 


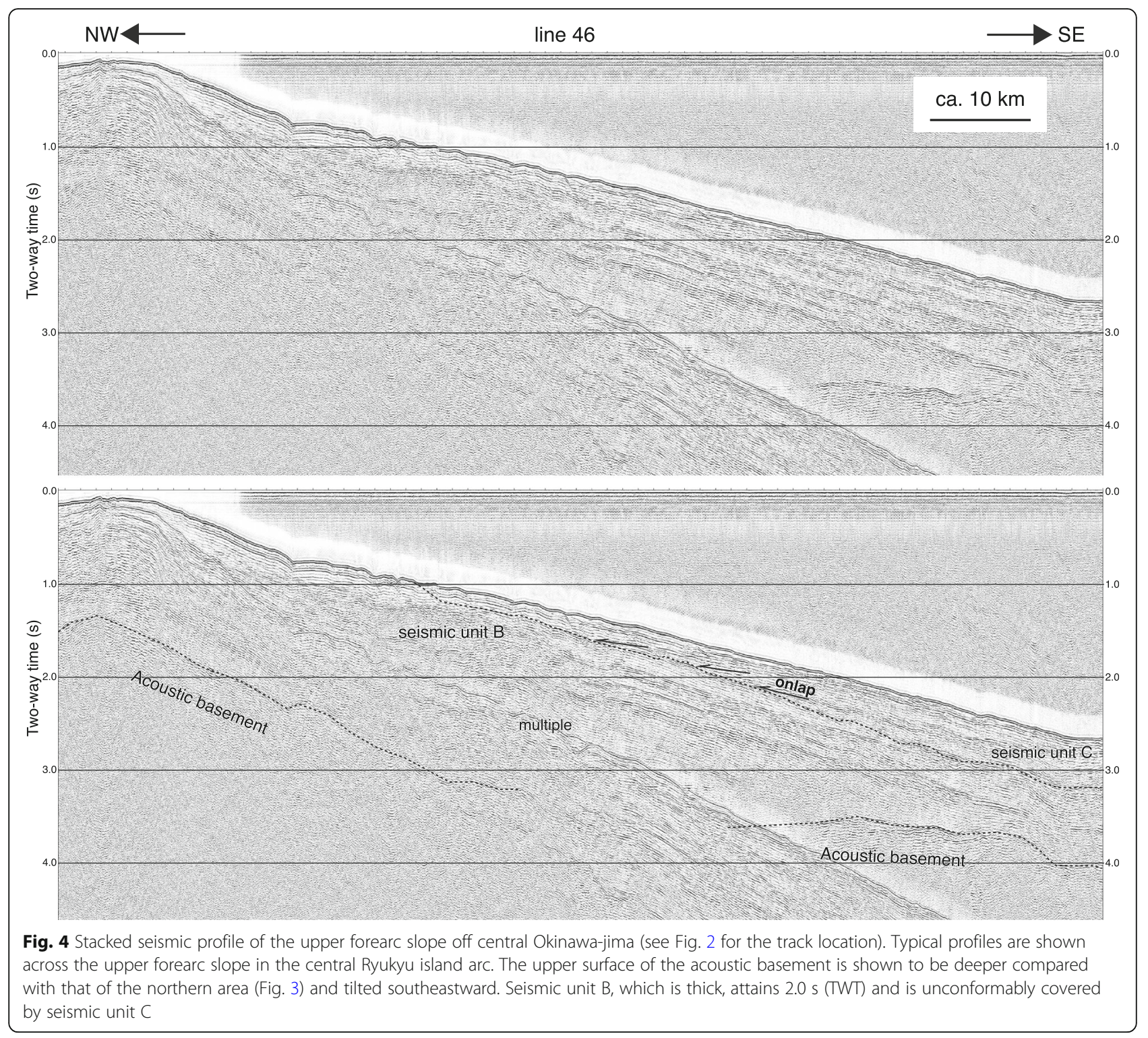

by the first occurrence of large Gephyrocapsa oceanica (Datum 11, 1706 ka: Sato et al. 2009) and the first occurrence of Gephyrocapsa spp. (Datum 10, 1392 ka: Sato et al. 2009). Based on the biostratigraphy of a semi-consolidated sample from the upper part of seismic unit $C$ (Fig. 8) and the thickness of seismic unit D $(0.25 \times 750 \mathrm{~m} / 1706-1392 \mathrm{ka})$, the recent average maximum vertical displacement component on the normal fault may be as high as $11.0-13.5 \mathrm{~cm} /$ kyear. The survey line in the southwest-northeast direction off the southeast of Okinawa-jima is shown in Fig. 9. The normal faults dip to the southwest and develop into basements with maximum vertical displacements of $<200 \mathrm{~ms}$ TWT. Lines of many minor normal faults that are untraceable can also be observed.

\section{Discussion}

\section{Features of forearc basins and active structures}

The survey area to the southeast of Okinawa-jima is located on the upper forearc slope of the central Ryukyu Arc. Unlike the Nankai Trough, which is the northeastern extension of the Ryukyu Trench in central Honshu (e.g., Park et al. 2003), the forearc between Amami-o-shima and Okinawa-jima is characterized by a relatively narrow slope that lacks large basins (Fig. 1). The trench axis and arc in the central Ryukyu Arc are sub-parallel to each other and separated by approximately $110 \mathrm{~km}$. The structure of the southern Ryukyu Arc, where the convergence direction of the PSP beneath the Eurasian Plate is approximately $45^{\circ}$ oblique to the trench, has been studied previously (e.g., Kuramoto and Konishi 1989; Lallemand et al. 




1999). At the southern end of the Ryukyu Arc west of $125.5^{\circ} \mathrm{E}$, a forearc basin is well developed and $\mathrm{E}-\mathrm{W}$ trending left-lateral faults have been identified. In contrast, the convergence direction of the central Ryukyu Arc is perpendicular to the trench. The forearc slope of the central Ryukyu Arc lacks a large forearc basin but has a narrow slope that dips to the southeast in the direction opposite to the plate convergence.

Lin et al. (2014) reported tectonic similarities between the Mw 9.3 Sumatra-Andaman earthquake in 2004 (e.g., Seeber et al. 2007; Sibuet et al. 2007) and "the southern Ryukyu" convergent subduction system, noting that both regions are characterized by oblique convergence with similar risks of large earthquakes and tsunamis. Meanwhile, Hsu et al. (2013) examined deep multichannel seismic reflection data along the trench, which show that a mega-splay fault has developed from southern to central Ryukyu from $125.5^{\circ} \mathrm{E}$ to $129.5^{\circ} \mathrm{E}$. This fault was generated under the influence of the outer ridge structure. While our seismic reflection data do not extend to the depths of the plate interface and mega-splay fault, Okamura et al. (2017) showed deep seismic reflection data and pointed out that the landward dipping reflections above the plate boundary are not active, at least not in the area between Miyako-jima and Okinawa-jima. In addition, even though further high-resolution seismic profiling will be necessary to confirm if the splay fault system extends fully into the central Ryukyu Arc, our data did not identify any obvious traceable deformations, such as folds and faults, parallel to the Ryukyu Trench axis. Furthermore, south of Miyako-jima (Hsu et al. 2013), our data showed no evidence for landward tilting 


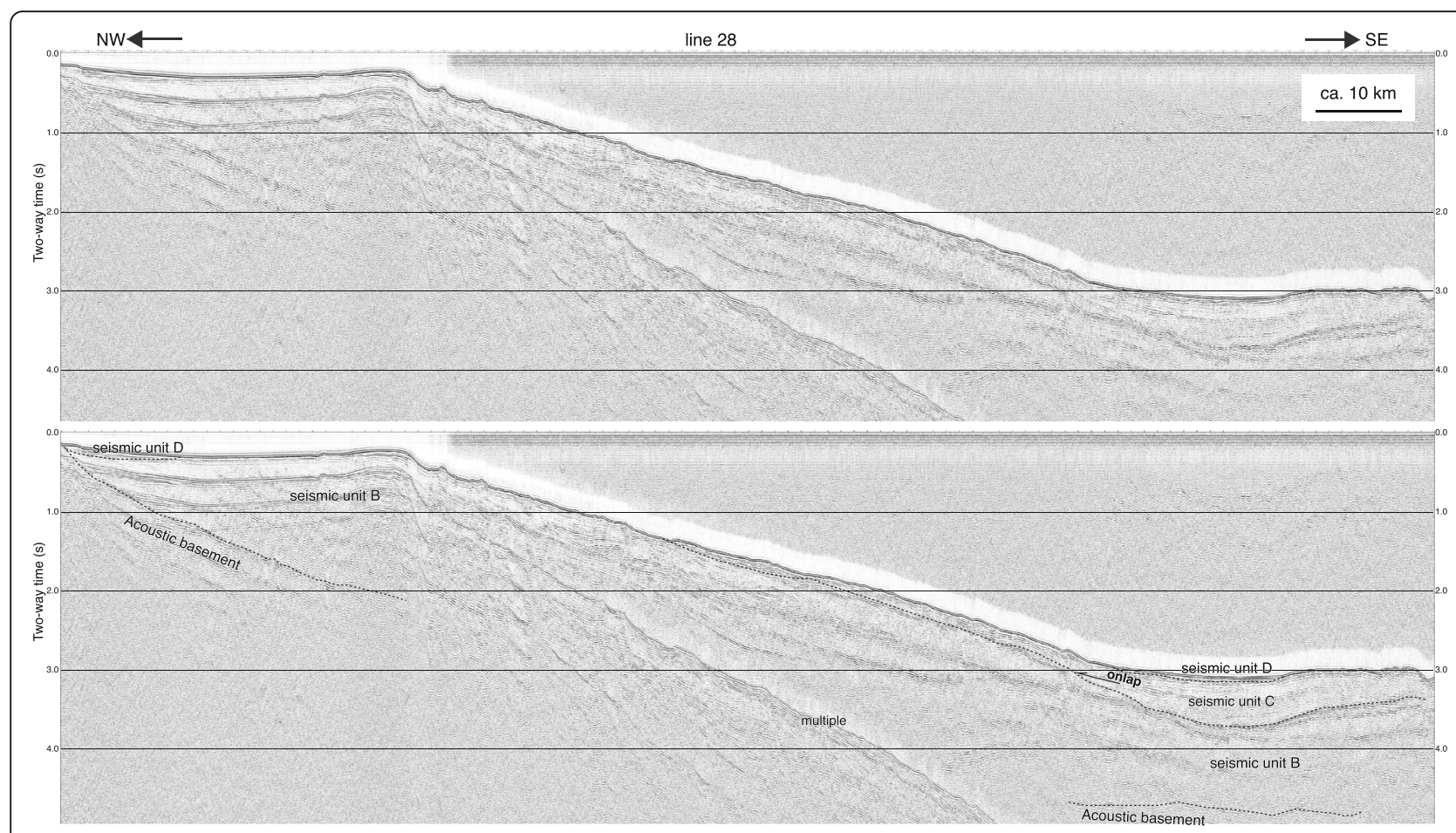

Fig. 6 Stacked seismic profile of the upper forearc slope (see Fig. 2 for the track location). The thick area of seismic unit B covering the acoustic basement has a thickness of $2.0 \mathrm{~s}$ (TWT). Seismic unit D, which is stratified, unconformably covers seismic Unit B on the island shelf

of sediments or normal faults parallel to the trench axis beneath the forearc slope. As such, even if mega-splay faults have developed beneath the accretionary prism, a large difference characterizes the forearc slopes of the southern and central Ryukyu Arc. This indicates that the compressional stress is concentrated beneath the lower trench slope area in the central Ryukyu Arc.

\section{Evolution of the upper forearc slope along the central Ryukyu arc}

Direct observations of geological structures on an overriding plate are important because forearc slope deformation is related to large earthquakes and tsunami generation. The convergent margin along the Sumatran subduction zone, where the Mw 9.3 Sumatra-Andaman Earthquake and related tsunami occurred in 2004, is characterized by thick sediments and prominent deformation in the form of large-scale frontal folds in the accretionary prism (Sibuet et al. 2007). The distance from the trench axis to the arc in northern Sumatra is approximately $250 \mathrm{~km}$, and the forearc Aceh Basin is located sub-parallel to the trench axis. The boundary between the Aceh Basin and the forearc region is marked by the West Andaman Fault, which has a flower structure, indicating strike-slip deformation on the landward side of the forearc high (e.g., Seeber et al. 2007). Numerous anticlinal ridges oriented sub-parallel to the trench have been found from the trench slope to forearc high by seismic reflection surveys (Misawa et al. 2014). Another example of a convergent margin is that of the Tohoku area along the Japan Trench, where the Mw 9.0 Great East Japan Earthquake and related tsunami occurred in 2011. Here, the upper forearc slope has a relatively flat seafloor topography that is inclined at $<3^{\circ}$, and recent tectonic deformation has been characterized by extensional subsidence and normal faulting within a series of small basins on the slope down to a water depth of $\sim 3000 \mathrm{~m}$ (Arai et al. 2014; Boston et al. 2017), which reveal extensional deformation related to the development of numerous normal faults sub-parallel to the trench axis.

The lack of arc-parallel structures is characteristic of the upper plate of the central Ryukyu Arc. Kubo and Fukuyama (2003) along with Otsubo et al. (2008) reported an arc-parallel extensional stress field along the forearc of the Ryukyu Arc, as inferred from the focal mechanisms of shallow earthquakes. The latest Miocene to Pliocene stress field of the northern Ryukyu Arc has been studied by Yamaji (2003), who reported an active back-arc rift, a neutral stress forearc, and an active accretionary prism in the northern Ryukyu Arc. The extensional tectonics is suggested by active normal faults in the Tanega-shima, Okinawa-jima, and Miyako-jima area (Research Group for Active Faults of Japan 1991) and on-land geology in Okinawa-jima, Miyako-jima, and Kikai-jima (Ujiié 1994). Our investigation of the offshore area is consistent with those of the on-land stress field. 


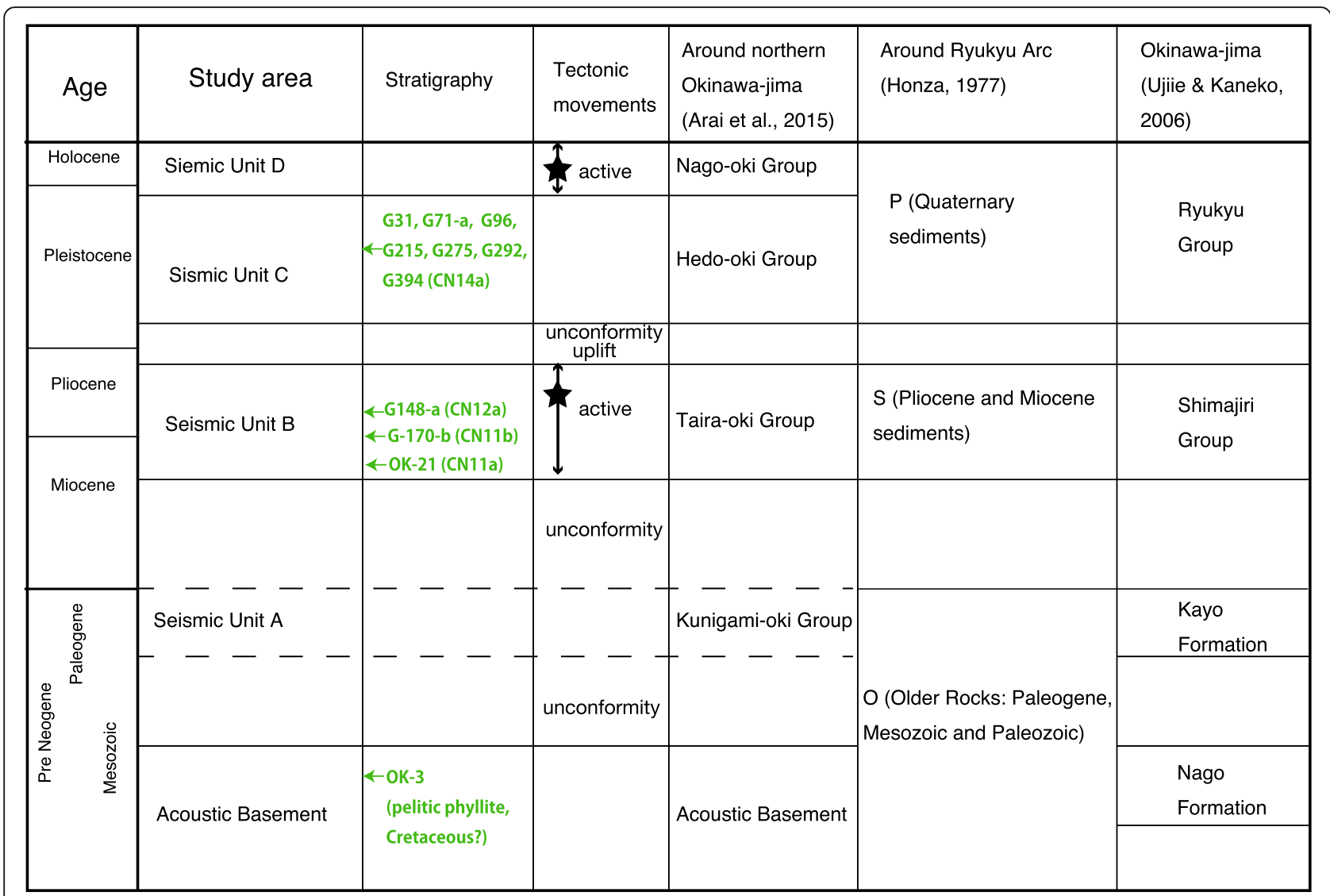

Fig. 7 Stratigraphy of the studied area, modified after Arai et al. (2015); Honza, E (1977); Ujié H, Kaneko N (2006). Green arrows show the stratigraphic position of samples and calcareous nannofossil biostratigraphic zonation (Okada and Bukry 1980)

Kubo and Fukuyama (2003) considered two possible arc-parallel extension mechanisms. One attributes the arc-parallel extension in the forearc to the drag of the dextral oblique subduction along the Ryukyu Trench, whereas the other attributes it to forearc elongation due to simultaneous arc-perpendicular extension in the back-arc. In our investigation into the deformation of the Ryukyu Arc using the high-density seismic profiles, we found that the normal faults parallel to the trench axis are well developed on the back-arc side of the arc (Fig. 10), thereby indicating back-arc rifting. Growth strata in sedimentary units indicate that the fault activity was high during the sedimentation of seismic unit B in the late Miocene to early Pleistocene, and during the more recent sedimentation of seismic unit D. The sediment layers of seismic unit $\mathrm{C}$ (Pleistocene) are sub-parallel to each other in the basin, which may indicate that extensional tectonics had ceased during its deposition (Fig. 10). The similar stratigraphy of growth strata adjacent to the fault in the upper forearc slope (Fig. 8) and back-arc side indicates that back-arc rifting of the Okinawa Trough resulted in arc-parallel extension (Fig. 11). Our data suggest that the arc-parallel extensional stress along the entire forearc of the Ryukyu Arc ceased during the Pleistocene (i.e., during the deposition of seismic unit C). These geological data support the Kubo and Fukuyama (2003) model, which shows the elongation of the forearc by simultaneous arc-perpendicular extension in the back-arc and indicates two stages of extensional stress beneath the forearc slope of the central Ryukyu Arc. Since these tectonic events activate at the same time, we consider it likely that the overriding plate has undergone significant deformation as a result of back-arc rifting activity in the Okinawa Trough.

Regarding the on-land geology, Ujiié (1994) suggested that the initial appearance of the Okinawa Trough and the Ryukyu Arc occurred after the deposition of the Shimajiri Group (which corresponds to seismic unit B) and before that of the Ryukyu Group (which corresponds to seismic units $C$ and $D$ ) during the early Pleistocene age. In addition, Gungor et al. (2012) hypothesized, based on the seismic profiles, that rifting and extension of the northern Okinawa Trough has continued since the late Miocene. Based on the growth strata developments, we contend that rifting of the Okinawa Trough initiated during the deposition of the seismic unit B (late Miocene to early Pleistocene) that accompanies the arc parallel extensional deformation at the 


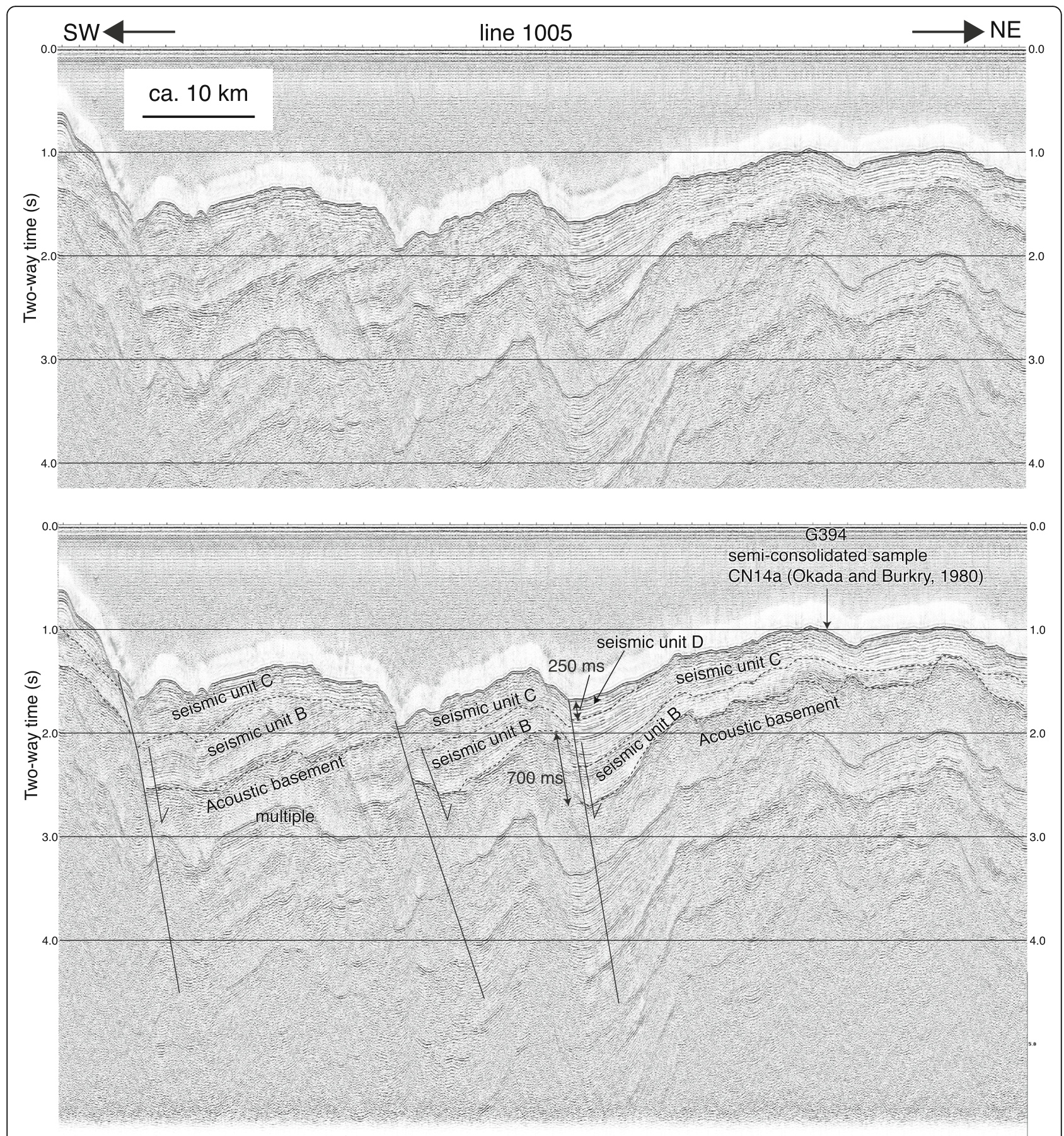

Fig. 8 Stacked seismic profile of the upper forearc slope east of Okinawa-jima and Yoron-jima islands (see Fig. 2 for the track location). Normal faults that are oriented perpendicular to the Ryukyu island arc and the Ryukyu Trench axis are evident. The most obvious fault bounds a half-graben structure

forearc slope. However, we could not estimate the deformation activity resulting from unconformity between seismic units $B$ and $C$ from our data, because extensional tectonics had ceased during the deposition of seismic unit $\mathrm{C}$ and a series of movements had become prominent during its deposition of seismic unit $\mathrm{D}$. Among our differences with the on-land geological history outlined by Ujiié (1994) is the timing of the initiation of the Okinawa Trough, which will require further examination.

Nevertheless, from our results, it is clear that two stages of extensional stress beneath the forearc slope of the central Ryukyu Arc, the late Miocene to early Pleistocene (seismic 


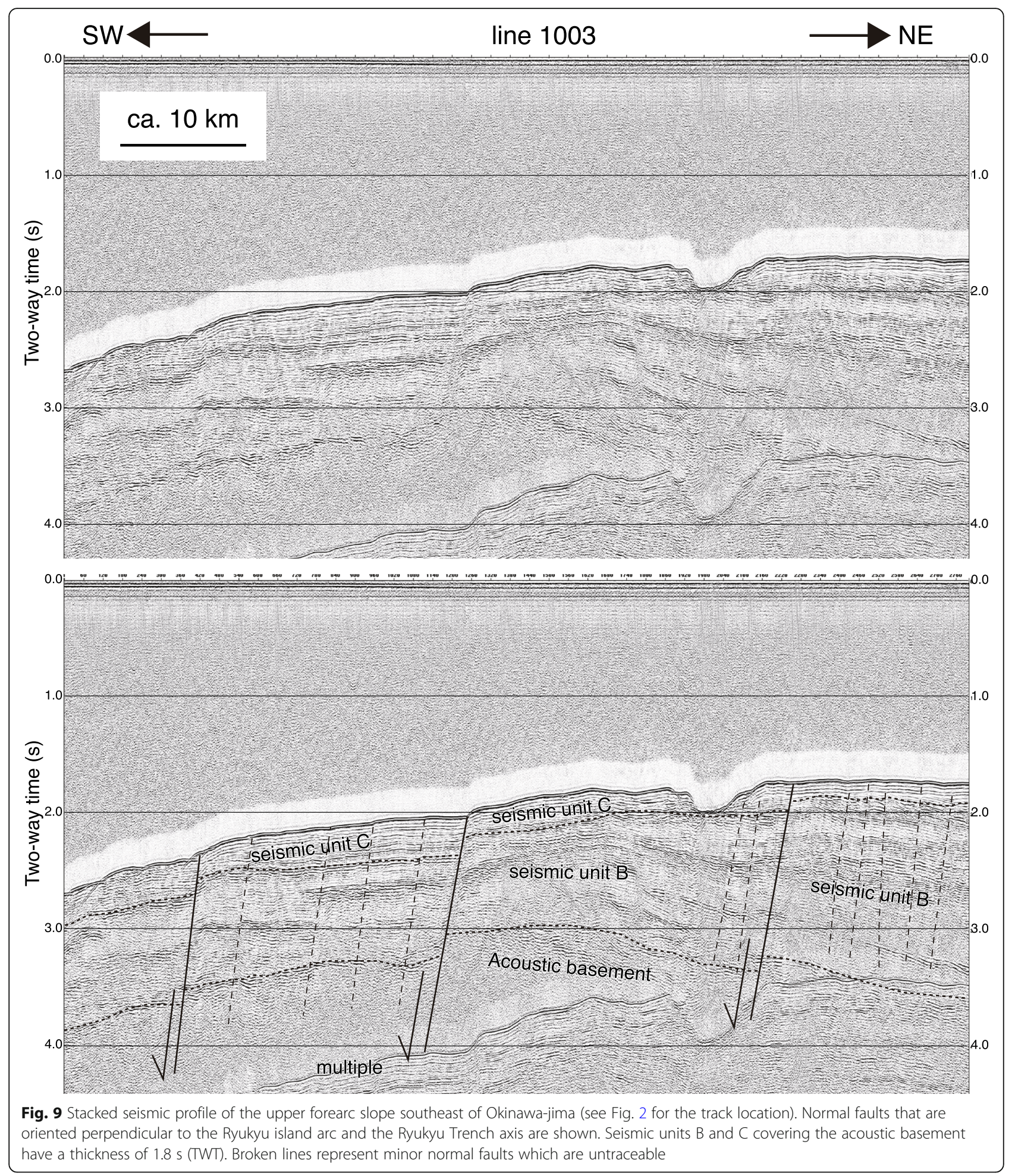

unit B) and the late Pleistocene (seismic unit D), occurred simultaneously in the back-arc of the Okinawa Trough. Furthermore, examinations of high-density geological data show that the recent relative motion of the overriding plate has resulted in an active, arc-parallel extensional stress beneath the forearc slope of the central Ryukyu Arc.

\section{Conclusions}

A total of $\sim 12,000 \mathrm{~km}$ high-resolution 16-channel seismic profiles were collected around Okinawa-jima in the central Ryukyu Arc off Japan. Our results show that the forearc slope of the central Ryukyu Arc lacks large forearc basins and has a steep narrow slope that dips to the 

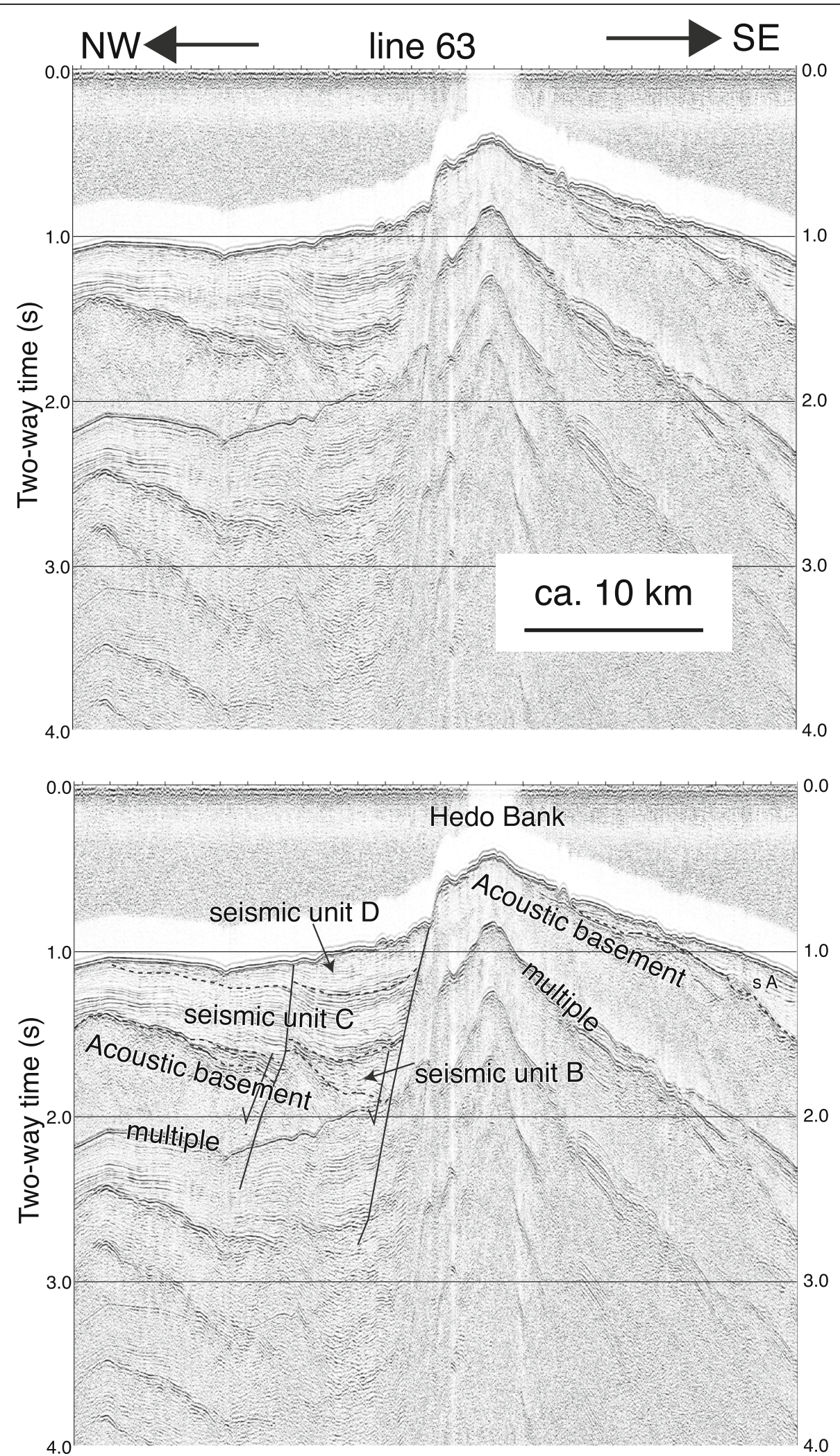

Fig. 10 Stacked seismic profiles across the southern Yoron Basin (see Fig. 2 for the track location). Traceable normal faults are located in the Yoron Basin. The faults strike east-west and dip to the north. The faults have deformed the uppermost sediments, thereby indicating that they are active 




southeast, opposite to the direction of plate convergence. The seismic profiles we collected do not show active structures indicative of compressional stress in a convergent subduction zone. Instead, recent tectonic deformation is characterized by normal faults that are oriented perpendicular to the Ryukyu Trench axis. From these results, two stages of extensional stress beneath the forearc slope of the central Ryukyu Arc, the late Miocene to early Pleistocene and the late Pleistocene, have been affected by back-arc rifting in the Okinawa Trough.
Additionally, our data suggest that such back-arc rifting played an important role in the evolution of the upper forearc slope along the central Ryukyu Trench. Taken together, these results confirm that not only do the high-density seismic profiles show the detailed structural deformation and distribution around islands, but they also show that geological structures on the overriding plate play an important role in understanding the plate's contribution to the generation of large earthquakes and subsequent tsunamis. 


\section{Abbreviations}

AIST: National Institute of Advanced Industrial Science and Technology; GSJ: Geological Survey of Japan; IGG: Research Institute of Geology and Geoinformation; JOGMEC: Japan Oil, Gas and Metals National Corporation; PSP: Philippine Sea Plate

\section{Acknowledgements}

This study was carried out as a part of the "Geological Mapping Project Around Okinawa Islands" by the Geological Survey of Japan (GSJ) of the National Institute of Advanced Industrial Science and Technology (AIST). We are grateful to Captain Hiroshi Futami and the crew of the R/V Hakurei-maru No. 2 for the professionalism they displayed during the cruises. We are also indebted to scientific members of the $\mathrm{GH} 08, \mathrm{GH} 09$, and $\mathrm{GH} 10$ cruises and to project leader Ken Ikehara of the GSJ-AIST's Research Institute of Geology and Geoinformation (IGG) for providing valuable advice in preparation for these cruises. In addition, we are deeply indebted to Y. Iryu for his editorial work and to the two anonymous reviewers whose constructive comments and suggestions have improved our manuscript.

\section{Funding}

This work was carried out as a part of the "Geological Mapping Project Around Okinawa Islands" by the GSJ-AIST.

\section{Availability of data and materials}

Please contact the corresponding author for data requests.

\section{Authors' contributions}

KA proposed the topic and then conceived and designed the study. TI contributed to the acquisition and interpretation of seismic reflection survey data. TS analyzed the data and helped in their interpretation. All of the authors have read and approved the final manuscript.

\section{Authors' information}

KA is the Deputy Director of the Research Institute of Geology and Geoinformation (IGG), the Geological Survey of Japan (GSJ) of the National Institute of Advanced Industrial Science and Technology (AIST). TI and TS are senior researchers in the Marine Geology Research Group in the IGG and experts on seismic reflection surveys. All authors are members of the "Geological Mapping Project Around Okinawa Islands."

\section{Competing interests}

The authors declare that they have no competing interests.

\section{Publisher's Note}

Springer Nature remains neutral with regard to jurisdictional claims in published maps and institutional affiliations.

\section{Received: 19 March 2018 Accepted: 27 July 2018}

\section{Published online: 24 August 2018}

\section{References}

Amante C, Eakins BW (2009) ETOPO1 1 arc-minute global relief model: procedures, data sources and analysis. NOAA Technical Memorandum NESDIS NGDC-24, National Oceanic and Atmospheric Administration (NOAA), Washington, DC.

Ando M, Nakamura M, Matsumoto T, Furukawa M, Tadokoro K, Furumuto M (2009) Is the Ryukyu subduction zone in Japan coupled or decoupled? - the necessity of seafloor crustal deformation observation. Earth Planets Space 61: 1031-1039.

Arai K, Inoue T, Ikehara K, Sasaki T (2014) Episodic subsidence and active deformation of the forearc slope along the Japan Trench near the epicenter of the 2011 Tohoku Earthquake. Earth Planet Sci Lett 408:9-15. https://doi. org/10.1016/j.epsl.2014.09.048.

Arai K, Inoue T, Sato T (in press) Geological map of the vicinity of southern Okinawa-Jima island. Marine Geology Map Series 90 (CD). Geological Survey of Japan, AIST. (in Japanese with English abstract).

Arai K, Inoue T, Sato T, TuZino T, Murakami F (2010) 16ch high-resolution seismic reflection surveys on the active fault of upper fore-arc slope off Okinawa Island, central Ryukyu Island Arc, Southwest Japan, in: AGU Fall Meeting T22A-06.
Arai K, Sato T, Inoue T (2015) Geological map of the vicinity of northern OkinawaJima island. Marine Geology Map Series 85 (CD). Geological Survey of Japan, AIST. (in Japanese with English abstract).

Araoka D, Yokoyama Y, Suzuki A, Goto K, Miyagi K, Miyazaki K, Matsuzaki H, Kawahata H (2013) Tsunami recurrence revealed by Porites coral boulders in the southern Ryukyu Islands, Japan. Geology 41:919-922. https://doi.org/10. 1130/G34415.1.

Boston B, Moore GF, Nakamura Y, Kodaira S (2017) Forearc slope deformation above the Japan Trench megathrust: implications for subduction erosion. Earth Planet Sci Lett 462:26-34. https://doi.org/10.1016/j.epsl.2017.01.005.

Fukuta O, Motojima K, ljima S, Kino Y, Suzuki T, Ogawa K, Suda Y, Shimizu M, Inoue M, Goto H, Maki S, Natori H, Koma T (1969) Natural gas resources of the Ryukyu Islands - preliminary report by the 4th Phase Survey of G.S.J. Bull Geol Surv Japan 20:101-124.

Goto K, Miyagi K, Imamura F (2013) Localized tsunamigenic earthquakes inferred from preferential distribution of coastal boulders on the Ryukyu Islands, Japan. Geology 41:1139-1142. https://doi.org/10.1130/G34823.1.

Goto K, Miyagi K, Kawamata H, Imamura F (2010) Discrimination of boulders deposited by tsunamis and storm waves at Ishigaki Island, Japan. Mar Geol 269:34-45. https://doi.org/10.1016/j.margeo.2009.12.004.

Gungor A, Lee GH, Kim HJ, Han HC, Kang MH, Kim J, Sunwoo D (2012) Structural characteristics of the northern Okinawa Trough and adjacent areas from regional seismic reflection data: geologic and tectonic implications. Tectonophysics 522-523:198-207.

Honza, E (1977) Geological map around Ryukyu arc, 1:1,000,000 Marine Geology Map Series 7. Geological Survey of Japan.

Hsu SK, Yeh YC, Sibuet JC, Doo WB, Tsai C-H (2013) A mega-splay fault system and tsunami hazard in the southern Ryukyu subduction zone. Earth Planet Sci Lett 362:99-107.

Iryu Y, Matsuda H, Machiyama H, Piller WE, Quinn TM, Mutti M (2006) An introductory perspective on the COREF Project. Island Arc 15:393-406.

Kato S, Katsura T, Hirano K (1982) Submarine geology off Okinawa Island. Rep Hydrograp Res 17:31-70 (in Japanese with English abstract).

Kizaki K (1978) Tectonics of the Ryukyu Island Arc. J Phys Earth 26(Suppl):S301-S307.

Konishi K (1965) Geotectonic framework of the Ryukyu Islands (Nansei-shoto). J Geol Soc Jpn 71:437-457 (in Japanese with English abstract).

Kubo A, Fukuyama E (2003) Stress field along the Ryukyu Arc and Okinawa Trough inferred from moment tensors of shallow earthquakes. Earth Planet Sci Lett 210:305-316.

Kuramoto S, Konishi K (1989) The southwest Ryukyu arc is a migrating microplate (forearc sliver). Tectonophysics 163:75-91.

Lallemand S, Liu CS, Dominguez S, Schnürle P, Malavieille J (1999) Trench-parallel stretching and folding of forearc basins and lateral migration of the accretionary wedge in the southern Ryukyus: a case of strain partition caused by oblique convergence. Tectonics 18:231-247.

Letouzey J, Kimura M (1986) The Okinawa Trough: genesis of a back-arc basin developing along a continental margin. Tectonophysics 125:209-230.

Lin JY, Sibuet JC, Hsu SK, Wu WN (2014) Could a Sumatra-like megathrust earthquake occur in the south Ryukyu subduction zone? Earth Planets Space 66:49. https://doi.org/10.1186/1880-5981-66-49.

Misawa A, Hirata K, Seeber L, Arai K, Nakamura Y, Rahardiawan R, Udrekh U, Fujiwara T, Kinoshita M, Baba H, Kameo K, Adachi K, Sarukawa H, Tokuyama H, Permana H, Djajadihardja YS, Ashi J (2014) Geological structures of the offshore Sumatra forearc region estimated from high-resolution MCS reflection survey. Earth Planet Sci Lett 386:41-51.

Nakata T, Kawana T (1995) Historical and prehistorical large tsunamis in the southern Ryukyus, Japan. In: Tsuchiya Y, Shuto N (eds) Tsunami: progress in prediction, disaster prevention and warning. Kluwer Academic Publishers, Dordrecht, pp 211-222.

Okada H, Bukry D (1980) Supplementary modification and biostratigraphic zonation (Bukry, 1973, 1975). Mar Micropaleontol 5:321-325.

Okamura Y, Nishiwzawa A, Oikawa M, Horiuchi D (2017) Differential subsidence of the forearc wedge of the Ryukyu (Nansei-Shoto) Arc caused by subduction of ridges on the Philippine Sea Plate. Tectonophysics 717: 399-412.

Otsubo M, Yamaji A, Kubo A (2008) Determination of stresses from heterogeneous focal mechanism data: an adaptation of the multiple inverse method. Tectonophysics 457:150-160.

Park JO, Moore GF, Tsuru T, Kodaira S, Kaneda Y (2003) A subducted oceanic ridge influencing the Nankai megathrust earthquake rupture. Earth Planet Sci Lett 217:77-84 
Park JO, Tokuyama H, Shinohara M, Suyehiro K, Taira A (1998) Seismic record of tectonic evolution and backarc rifting in the southern Ryukyu island arc system. Tectonophysics 294:21-42.

Research Group for Active Faults of Japan (1991) Active faults in Japan: sheet maps and inventories, Revised edn. University of Tokyo Press (in Japanese with English abstract).

Sato T, Chiyonobu S, Hodell DA (2009) Data report: quaternary calcareous nannofossil datums and biochronology in the North Atlantic Ocean, IODP Site U1308. In: Channell JET, Kanamatsu T, Sato T et al (eds) Proc. IODP, 303/ 306, College Station TX (Integrated Ocean Drilling Program), pp 1-9.

Seeber L, Muller C, Fujiwara T, Arai K, Soh W, Djajadihardja YS, Cormier MH (2007) Accretion, mass wasting, and partitioned strain over the 26 Dec 2004 Mw9.2 rupture offshore Aceh, northern Sumatra. Earth Planet Sci Lett 263:16-31.

Seno T, Stein S, Gripp AE (1993) A model for the motion of the Philippine Sea Plate consistent with NUVEL-1 and geological data. J Geophys Res 89: 17941-17948.

Shinjo R (1999) Geochemistry of high Mg andesites and the tectonic evolution of the Okinawa Trough-Ryukyu arc system. Chem Geol 157:69-88.

Sibuet JC, Deffontaines B, Hsu SK, Thareau N, Le Formal JP, Liu CS, Party A (1998) Okinawa Trough backarc basin: early tectonic and magnetic evolution. J Geophys Res 103(B12):30245-30267.

Sibuet JC, Rangin C, Le Pichon X, Singh S, Cattaneo, Graindorge D, Klingelhoefe F, Lin JY, Malod J, Maury T, Schneider JL, Sultan N, Umber M, Yamaguchi H, Sumatra aftershocks Team (2007) 26th December 2004 great SumatraAndaman earthquake: co-seismic and post-seismic motions in northern Sumatra. Earth Planet Sci Lett 263:88-103.

Tanaka Y (2009) Calcareous nannofossil biochronology in sea-bottom sediments off Okinawa, Japan. Marine Geological and Geophysical Studies around Okinawa Island -eastern off of Okinawa Island- Preliminary Reports on Researches in the 2008 Fiscal Year, GSJ Interim Report, no. 46: 93-95 (in Japanese).

Tsuji Y (1997) Damage to villages on Amami Archipelago due to the 1995 Amami-Oshima-Kikai earthquake-tsunami. J Geogr 106:486-502. https://doi. org/10.5026/jgeography.106.4_486.

Ujié H (1994) Early Pleistocene birth of the Okinawa Trough and Ryukyu Island Arc at the northern margin of the Pacific: evidence from Late Cenozoic planktonic foraminiferal zonation, Palaeogeography, Palaeoclimatology. Palaeoecology 108:457-474.

Ujiié H, Kaneko N (2006) Geology of the Naha and Okinawashi-Nambu district. Quadrangle series, 1:50,000, Geological Survey of Japan, AIST, p 48 (in Japanese with English abstract).

Watanabe H (1985) A comprehensive list of tsunami damage in Japan. University of Tokyo Press, Tokyo, 206.

Yamaji A (2003) Slab rollback suggested by latest Miocene to Pliocene forearc stress and migration of volcanic front in southern Kyusyu, northern Ryukyu Arc. Tectonophysics 364:9-24

\section{Submit your manuscript to a SpringerOpen ${ }^{\circ}$ journal and benefit from:}

- Convenient online submission

- Rigorous peer review

- Open access: articles freely available online

- High visibility within the field

- Retaining the copyright to your article

Submit your next manuscript at $\boldsymbol{\nabla}$ springeropen.com 